\title{
Heat Treatment Reduces Bacterial Contamination of Medicinal Plants Grown in A Community Garden
}

\author{
Cleusa Fernandes $\operatorname{Ramos}^{1}(\mathbb{D})$, Andreia Assuncao Soares ${ }^{2 *}(\mathbb{D}$, Isabela Carvalho dos \\ Santos $^{3}$ (D), Felipe Andre Pereira Ramos ${ }^{4}$ (D) , Odair Alberton ${ }^{5}$ (D) , Luciana Kazue \\ Otutumi ${ }^{6}(\mathbb{D})$, Lidiane Nunes Barbosa ${ }^{6}{ }^{(D)}$, Ricardo de Melo Germano ${ }^{7}$, Daniela \\ Dib Goncalves $^{8}$ iD and Luiz Sergio Merlini ${ }^{9}$
}

\begin{abstract}
${ }^{1}$ Master in Animal Science with an Emphasis on Bioactive Products, Paranaense University (UNIPAR), Umuarama, Parana, Brazil.

2Professor at Post-Graduation Programs in Animal Science with an Emphasis in Bioactive Products and Professional Master's Degree in Medicinal and Phytotherapic Plants at Primary Care, Paranaense University (UNIPAR), Umuarama, Parana, Brazil.

${ }^{3}$ Doctoral student in the Post-Graduation Program in Animal Science with an Emphasis on Bioactive Products, (Scholarship holder PROSUP / CAPES, UNIPAR-PR); Paranaense University (UNIPAR), Umuarama, Parana, Brazil. ${ }^{4}$ Master's student of the Post-Graduation Program in Medicinal Plants and Herbal Medicines at Primary Care, Paranaense University (UNIPAR), Umuarama, Parana, Brazil.

${ }^{5}$ Professor at Post-Graduation Program - Professional Master's Degree in Medicinal Plants and Phytotherapies at Primary Care, Paranaense University (UNIPAR), Umuarama, Parana, Brazil.

${ }^{6}$ Professor of the Post-Graduation Program in Animal Science with an Emphasis on Bioactive Products, Paranaense University (UNIPAR), Umuarama, Parana, Brazil.

${ }^{7}$ Professor of Post-Graduation Programs in Animal Science with an Emphasis in Bioactive Products and Professional Master's Degree in Medicinal and Phytotherapeutic Plants at primary care, Paranaense University (UNIPAR), Umuarama, Parana, Brazil.

${ }^{8}$ Professor of Post-Graduation Programs in Animal Science with an Emphasis in Bioactive Products and Professional Master's Degree in Medicinal and Phytotherapeutic Plants at Atencao Basica, Paranaense University (UNIPAR), Umuarama, Parana, Brazil.

${ }^{9}$ Professor of the Post-Graduation Program in Animal Science with an Emphasis on Bioactive Products, Paranaense University (UNIPAR), Umuarama, Parana, Brazil.
\end{abstract}

\begin{abstract}
*Correspondence: andreia.assuncao@prof.unipar.br
(Received: May 01, 2020; accepted: August 24, 2020)

Citation: Ramos CF, Soares AA, dos Santos IC, et al. Heat Treatment Reduces Bacterial Contamination of Medicinal Plants Grown in A Community Garden. J Pure Appl Microbiol. 2020;14(3):1817-1823. doi: 10.22207/JPAM.14.3.20

C The Author(s) 2020. Open Access. This article is distributed under the terms of the Creative Commons Attribution 4.0 International License which permits unrestricted use, sharing, distribution, and reproduction in any medium, provided you give appropriate credit to the original author(s) and the source, provide a link to the Creative Commons license, and indicate if changes were made.
\end{abstract}




\begin{abstract}
The verification of microorganisms that indicate contamination of medicinal plants cultivated in vegetable gardens is fundamental to contribute and improve the conditions and management of the garden, providing safer and healthier food for the consumer population. The study aims to evaluate the bacteriological quality of Cymbopogon citratus, Aloysia citriodora, Plectranthus barbalus, Aloe vera (L.) Burm. F., Sedum dendroideum, and Peumus boldus cultivated in community gardens. Six samples were randomly collected from each plant and sent to the Laboratory of Veterinary Preventive Medicine and Public Health at Universidade Paranaense-UNIPAR, for bacteriological analysis (aerobic mesophilic microorganisms, total coliforms and coliforms at $45 \circ \mathrm{C}$. The cold extract (room temperature) of the medicinal plants evaluated, the Plectranthus barbalus had the highest mean for aerobic mesophiles (1.26 CFU/g x 10 $)$ and the Cymbopogon citratus second highest mean for aerobic mesophiles (9.80 $\left.\mathrm{CFU} / \mathrm{g} \times 10^{5}\right)$. In the coliform count at $45^{\circ} \mathrm{C}$, the highest mean was found in the Aloysia citriodora (2.90 $\left.\mathrm{CFU} / \mathrm{g} \times 10^{3}\right)$ and it presented the second lowest mean for coliforms at $45^{\circ} \mathrm{C}\left(0.63 \mathrm{CFU} / \mathrm{g} \times 10^{3}\right)$ and was zero for total coliforms. Regarding the hot extract $\left(95^{\circ} \mathrm{C}-100^{\circ} \mathrm{C}\right)$ of the medicinal plants evaluated, a significantly higher aerobic mesophiles count was found for Aloysia citriodora when compared with Aloe vera (L.) Burm. F., Sedum dendroideum and Peumus boldus, not differing statistically from Cymbopogon citratus and Plectranthus barbalus. It was found that medicinal plants are contaminated but, since they are indicated as teas (infusion), they are safe for their consumers because the risk of bacteriological contamination can be considerably eliminated or reduced due to the boiling process.

Keywords: Aerobic Mesophiles, Food Safety, Microbiology, Public Health, Total Coliforms
\end{abstract}

\section{INTRODUCTION}

The cultivation of food species in home gardens favors access to fresh food in quantity and quality, which contributes to food and nutritional security ${ }^{1}$. These characteristics of vegetables contribute positively to health, as they act as functional/nutraceutical foods, helping to improve health and well-being and/or reduce the risk of diseases, in addition to providing pleasure/taste of planting, cultivar, occupation and therapy ${ }^{2}$.

With the growing search for natural products and their derivatives, a more careful assessment of the quality of the products offered to the consumer must be carried out, based on specific legislation, controlling all stages of production. The control and evaluation of the microbiological and parasitological load of medicinal plants are determinant for quality assurance and, if they are not properly complied with, may compromise their use as adjuvant in improving the individual's health status s.5. $^{3-5}$.

Henz and Alcantara ${ }^{6}$ defines a community garden as one that is grown jointly by groups of families or people from a community, by means of production cooperatives, who are responsible for managing production. In general, they are installed in idle urban areas (public and private), used for the cultivation of vegetables, medicinal plants, production of seedlings, vegetables, fruits and other foods, which supply families living near these lands.

Another positive aspect of agricultural production in urban areas is the formation of eating habits, especially as the relationship between food and health is evident. The production and sale of vegetables benefits not only the families involved in the garden, but also the residents around the unit, who generally consume more food free of agrochemicals? ${ }^{7}$.

The World Health Organization estimates that $80 \%$ of people depend on traditional medicine ${ }^{8}$ and despite major advances in the pharmaceutical industry, the use of this alternative therapy is growing, which increases the responsibility of regulatory agencies and manufacturers, as they must ensure the quality and therapeutic efficacy of these products ${ }^{9}$. The organization responsible for the safety and efficacy of herbal products in Brazil is the National Health Surveillance Agency, however, these products are not considered with the same vigor as synthetic drugs ${ }^{10}$ and yet it is desirable and important that such products are within the minimum quality standards ${ }^{11}$.

Nevertheless, investigations of the microbiological quality of vegetable-based drugs and by-products obtained from them, 
carried out in other countries, showed rates of microbial contamination in disagreement with internationally accepted standards for drugs ${ }^{12}$, and in Brazil, microbiological evaluations of herbal medicines marketed in pharmacies showed similar results ${ }^{13}$.

Thus, the verification of microorganisms that indicate contamination of medicinal plants cultivated in vegetable gardens is fundamental to contribute and improve the conditions and management of the garden, providing safer and healthier food for the consumer population. The present work aims to evaluate the bacterial contamination by aerobic mesophiles, total coliforms and $45^{\circ} \mathrm{C}$ obtained through heat treatment in six medicinal plants grown in a community garden.

\section{MATERIAL AND METHODS}

The survey was conducted in the community garden of the State School of Campo
Benjamim Antonio Motter, located in the district of Central Santa Cruz, Cafelandia, state of Parana. The Municipality of Cafelandia is located in the western region of Parana, at latitude $24^{\circ}$ $36^{\prime} 12^{\prime \prime}$ and longitude $53^{\circ} 21^{\prime} 09^{\prime \prime}$, and its altitude is 550 meters and coordinates are $24^{\circ} 37^{\prime}$ South Latitude, $53^{\circ} 20^{\prime}$ Longitude W - GK.

Cafelandia is a predominantly agricultural municipality, largely due to the good natural fertility of its soils. Four types of soils are detected in the Municipality (Eutrophic Purple Latoil, Structured Purple Soil, Indiscriminate Hydromorphic Soils and Litholic Soils), with a predominance of Eutrophic Purple Latoil $(90.3 \%$ of the total area) and Structured Purple Soil $(8.0 \%)^{14}$. The medicinal plants were collected from May to July 2019, using gloves and previously sterilized material. This work was carried out with six species of medicinal plants, which were chosen for their availability at the time of this work and followed the procedure described in Fig. 1.

\section{Collection location: Community garden of the State School of Campo Benjamim Antônio Motter, located in the district of Central Santa Cruz, Cafelândia, state of Paraná.}
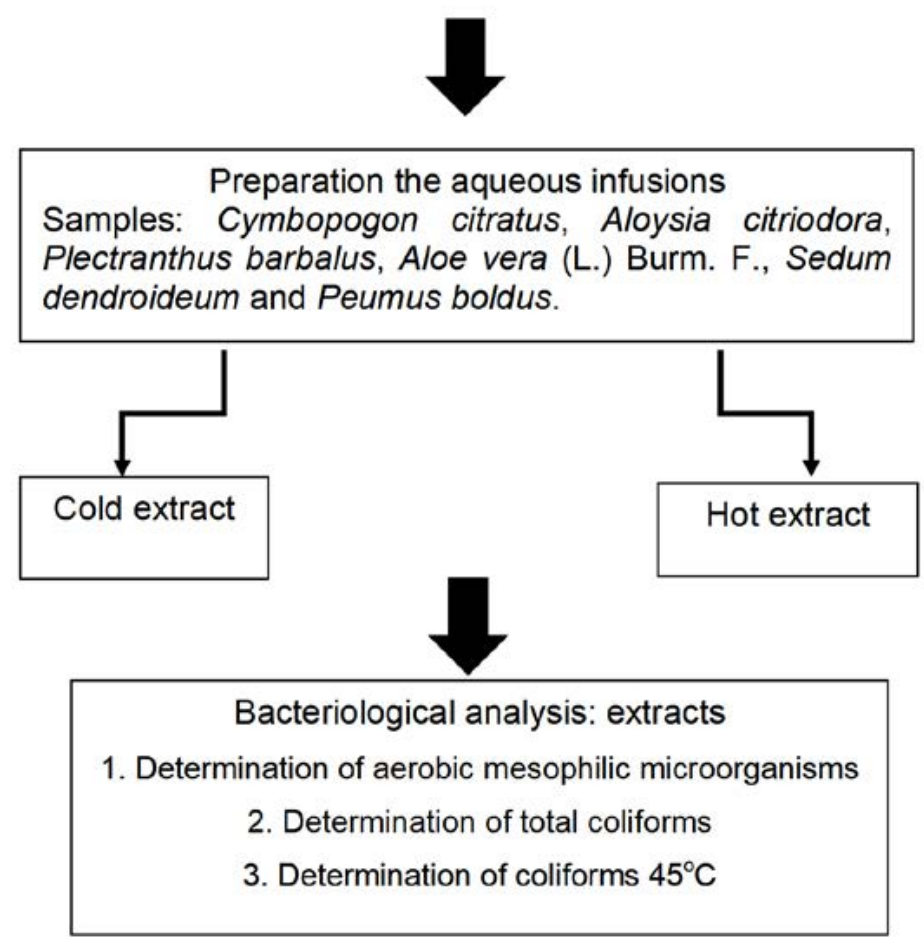

Fig. 1. Scheme of the processing stages of medicinal plants 
From the six species, two samples (to cold extract and hot extract) randomly chosen from different points were collected and the samples were packed in sterile Kraft paper bags with the appropriate identifications until processing in the UNIPAR Laboratory of Veterinary Preventive Medicine and Public Health.

In the laboratory, the samples of each species, after being weighed (10 grams of each sample), were transferred aseptically to different plastic bags, with hermetic closure. Then, the technique known as surface washing or rinsing was used to obtain the microorganisms present in medicinal plants ${ }^{15}$.

To determine aerobic mesophilic microorganisms, the methodology described by Silva et al. ${ }^{16}$ and Barbosa et al. ${ }^{17}$ was used with some modifications.

The culture medium used was Plate Count Agar (PCA) together with the surface seeding technique. Samples were analyzed by pipetting $0.1 \mathrm{~mL}$ aliquots or 100 microliters of the $10^{-1}, 10^{-2}$ and $10^{-3}$ dilutions to sterile petri dishes. The plates were homogenized and incubated inverted in an oven at $35^{\circ} \mathrm{C}$ for $24-48$ hours. After the incubation period, the colony forming units (CFU) were counted, aided by a colony counter where the number of plates between 25 and 250 colonies were considered for counting, multiplying the number of CFU by the respective dilution factor. The results were expressed in CFU/g (colony forming units/gram), considering the initial weight of the samples.

For the determination of total coliforms and coliforms at $45^{\circ} \mathrm{C}$, the methodology described by Bernadin et al. ${ }^{18}$ was used with some modifications.

An initial volume of $0.1 \mathrm{~mL}$ of each dilution $\left(10^{-1}, 10^{-2}\right.$ and $\left.10^{-3}\right)$ was used. It was inoculated in Brilliant Green (BG) culture medium for total coliform counts and in Escherichia coli (EC) culture medium for coliform analyses at $45^{\circ} \mathrm{C}$.

The inoculum was carefully spread over the entire surface until it was completely absorbed with the aid of a "Drigalski" strap. The BG plates were incubated in an incubator at $35^{\circ} \mathrm{C}$ for $24 \mathrm{~h}$ and the EC plates were incubated at $45^{\circ} \mathrm{C}$ for $48 \mathrm{~h}$.

Plates containing 15 to 150 colonies were considered for counting and the value corrected according to dilution. Results were expressed in CFU/g (colony forming units/gram), considering the initial weight of the samples.

Bacteriological analysis of medicinal plants (CFU/gram) was performed using the

Table 1. Mean of aerobic mesophilus count (CFU/gram), total coliforms (CFU/gram) and coliforms at $45^{\circ} \mathrm{C}$ (CFU/ gram) of the cold and hot extract of six different plants (Aloe vera L. Burm. F., Sedum dendroideum, Peumus boldus, Cymbopogon citratus, Aloysia citriodora and Plectranthus barbalus) collected in a community garden

\begin{tabular}{lccc}
\hline Medicinal plant & Aerobic mesophilesa* & $\begin{array}{c}\text { Total coliforms } \\
\text { Cold extract }\end{array}$ & Coliforms at $45^{\circ} \mathrm{C}^{\mathrm{b}}$ \\
\hline Aloe vera L. Burm. F. & $2.1 \times 10^{5 \mathrm{bc}}$ & $1.8 \times 10^{4 \mathrm{~cd}}$ & $0.67 \times 10^{3}$ \\
Sedum dendroideum & $5.0 \times 10^{4 \mathrm{bc}}$ & $2.3 \times 10^{3 \mathrm{~d}}$ & $0.70 \times 10^{3}$ \\
Peumus boldus & $2.6 \times 10^{3 \mathrm{~cd}}$ & $1.1 \times 10^{3 \mathrm{~d}}$ & $1.03 \times 10^{3}$ \\
Cymbopogon citratus & $9.8 \times 10^{5 \mathrm{ab}}$ & $1.6 \times 10^{5 \mathrm{ab}}$ & 0,00 \\
Aloysia citriodora & $7.4 \times 10^{5 \mathrm{ab}}$ & $4.1 \times 10^{4 \mathrm{bc}}$ & $2.90 \times 10^{3}$ \\
Plectranthus barbalus & $1.26 \times 10^{6 \mathrm{a}}$ & $2.6 \times 10^{3 \mathrm{~cd}}$ & $0.63 \times 10^{3}$ \\
& \multicolumn{2}{c}{ Hot extract $^{\mathrm{a}}$} & --- \\
Aloe vera L. Burm. F. & $0.07 \times 10^{3 \mathrm{c}}$ & --- & --- \\
Sedum dendroideum & $0.30 \times 10^{3 \mathrm{bc}}$ & --- & --- \\
Peumus boldus & $0.83 \times 10^{3 \mathrm{bc}}$ & --- & --- \\
Cymbopogon citratus & $1.83 \times 10^{3 \mathrm{ab}}$ & --- & -- \\
Aloysia citriodora & $3.17 \times 10^{3 \mathrm{a}}$ & -- & - \\
Plectranthus barbalus & $1.50 \times 10^{3 \mathrm{ab}}$ & & - \\
\hline
\end{tabular}

${ }^{a}$ Averages means followed by different letters in the column differ by Student-Newman-Keuls test $(P<0.05)$; b Not significant by Kruskal-wallis test ( $\mathrm{P}>0.05)$. *Standard to count of aerobic bacteria in plant drugs submitted to cold extraction process (10 5 $\mathrm{CFU} / \mathrm{g})$ and hot extraction process $\left(10^{7} \mathrm{CFU} / \mathrm{g}\right)$ 
Kruskall-wallis test, using the Bioestat 5.0 statistical program ${ }^{19}$. When relevant, the Student-NewmanKeuls test was chosen to compare means, and for all tests a $5 \%$ significance level was chosen.

\section{RESULTS}

There were variations in the count of the microorganisms evaluated in the present study for the different medicinal plants (Table 1).

For the cold extract, there was a higher $(P<0.05)$ aerobic mesophilic count for $P$. barbalus when compared to A. vera L. Burm. F., P. boldus and $S$. dendroideum, not differing $(P>0.05)$ from $C$. citratus and $A$. citriodora. On the other hand, in relation to the total coliform count, this plant presented the third lowest count $\left(2.6 \times 10^{3} \mathrm{CFU} / \mathrm{g}\right)$ differing $(P<0.05)$ only from $C$. citratus.

In the hot extract, there was a reduction in the aerobic mesophil count for all medicinal plants evaluated, however, $A$. citriodora had a higher ( $P$ $<0.05)$ count $\left(1.5 \times 10^{3} \mathrm{CFU} / \mathrm{g}\right)$ when compared to A. vera $\left(0.07 \times 10^{3} \mathrm{CFU} / \mathrm{g}\right)$, S. dendroideum $(0.3 \times$ $\left.10^{3} \mathrm{CFU} / \mathrm{g}\right)$ and $P$. boldus $\left(0.83 \times 10^{3} \mathrm{CFU} / \mathrm{g}\right)$.

Regarding total coliforms and at $45^{\circ} \mathrm{C}$, counting was found only for the cold extract (Table 1), with $C$. citratus presenting the highest $(\mathrm{P}<0.05)$ total coliform count $\left(1.6 \times 10^{5} \mathrm{CFU} / \mathrm{g}\right)$ when compared with $A$. vera $\left(1.8 \times 10^{4} \mathrm{CFU} / \mathrm{g}\right)$, S. dendroideum $\left(2.3 \times 10^{3} \mathrm{CFU} / \mathrm{g}\right)$, $P$. boldus (1.1 $\left.\times 10^{3} \mathrm{CFU} / \mathrm{g}\right)$ and $P$. barbalus $\left(2.6 \times 10^{3} \mathrm{CFU} / \mathrm{g}\right)$. For coliforms at $45^{\circ} \mathrm{C}$ there was no significant difference $(P>0.05)$ in the count for the different medicinal plants evaluated, and the highest mean was found for $A$. citriodora $\left(2.90 \times 10^{3} \mathrm{CFU} / \mathrm{g}\right)$.

\section{DISCUSSION}

Analyzing the results obtained, it was possible to observe that, with the exception of $P$. boldus and $S$. dendroideum, the other medicinal plants showed contamination above that established by Anvisa ${ }^{20}$, as published in Normative Instruction No. 4 of June 18, 2014, for the total aerobic bacteria count for the cold extract (Table 1).

According to this normative instruction, the total count of aerobic bacteria in plant drugs submitted to cold extraction process should be $10^{5}$ CFU/g, and to hot extraction process should be $10^{7} \mathrm{CFU} / \mathrm{g}^{20}$. The count of aerobic bacteria is used to obtain general information on product quality because products with high bacterial rates may indicate deficiency or low sanitary condition, but they may also be pathogenic ${ }^{16}$.

A similar work conducted by Marcondes and Esmerino ${ }^{15}$, showed that $82 \%$ of medicinal plants grown in domestic gardens in a district of Ponta Grossa (PR), analyzed before heat treatment, had an aerobic mesophilic count within the recommended by Normative Instruction No. 4 of June $18,2014^{20}$.

Similarly, Zaroni et al. ${ }^{21}$ evaluating 72 samples of medicinal plants without submitting them to the hot extraction process found that $41.67 \%$ of the samples met ANVISA's recommendation for aerobic mesophiles ${ }^{20}$.

In the present study, it was found that the count of aerobic mesophiles for $C$. citratus submitted to the cold extraction process was 9.8 $x 10^{5} \mathrm{CFU} / \mathrm{g}$, similar to that found by Zaroni et al. ${ }^{21}$ who verified counts varying between $8.5 \times 10^{5}$ and $1.7 \times 10^{7} \mathrm{CFU} / \mathrm{g}$ for the same extraction process.

Although there is no specific Brazilian legislation for plant drugs subjected to the cold or hot extraction process, the analysis of total coliforms and at $45^{\circ} \mathrm{C}$ is important, as they are microorganisms that indicate contamination, and the group of coliforms at $45^{\circ} \mathrm{C}$ it is most often used as an indicator of faecal contamination, however, it also inhabits environments such as the soil ${ }^{22}$. Thus, its presence in medicinal plants submitted to the cold extraction process in the present study, may be associated with soil or water contamination.

On the other hand, it should be noted that differences in the degree of contamination may be related to the distance from the soil surface on which the plant grows, presenting greater contamination the greater the proximity to the soil $^{23}$. Furthermore, according to the same authors the difference in the degree of contamination between medicinal plants can be explained by the fact that certain plants contain natural barriers and antimicrobial substances that have an effect on microbial growth.

Marcondes and Esmerino ${ }^{15}$ evaluating different medicinal plants grown in home gardens found that the contamination by total coliforms varied between $2.85 \times 10^{1}$ and $1.25 \times 10^{3} \mathrm{NMP} / \mathrm{g}$ of coliforms at $45^{\circ} \mathrm{C}$ from $4.3 \times 10^{1}$ to $1.71 \times$ $10^{2} \mathrm{NMP} / \mathrm{g}$. Similarly, Bernadin et al. ${ }^{18}$ found contamination of total coliforms and coliforms 
at $45^{\circ} \mathrm{C}$ in medicinal plants subjected to cold extraction, varying between $4 \times 10^{3}$ to $3.4 \times 10^{7}$ $\mathrm{CFU} / \mathrm{g}$ and $1 \times 10^{3}$ to $6.6 \times 10^{6} \mathrm{CFU} / \mathrm{g}$, being slightly higher than found in the present study (Table 1).

One of the important points to be taken into consideration was that after the heat treatment, coliforms were absent in all samples surveyed.

According to Alterthum and Carvalhal ${ }^{24}$, heat is one of the most widely used methods for inactivating microorganisms, because high temperatures cause them to be inactivated and irreversibly lose their ability to multiply. When a microbial population is heated, the reduction in the number of viable organisms occurs at high rates, justifying what was found in the present work.

With the considerable increase in medicinal plants or derived products, there is always a concern about their quality, which may lead to public health problems, due to the possibility of access to products without adequate conditions of consumption, resulting from the great potential for contamination linked to these products $^{25}$.

Microbiological quality control is one of the essential steps within this process, since microbiological contamination becomes a problem when it results in undesirable effects. Therefore, before using them in natura or commercialization, they must go through a rigorous control from collection and storage to final production, so that the quality and safety of the plants can be guaranteed $^{26}$. With these results, it is important to use medicinal plants in natura, as infusion or tea, to reduce or eliminate the microorganisms present.

\section{CONCLUSION}

Under the conditions in which the present research was carried out, it is concluded that in relation to the count of aerobic mesophiles, only two plants ( $P$. boldus and S. dendroideum) met the Brazilian legislation in force for the process of cold extraction of plant drugs.

In relation to the total coliforms and at $45^{\circ} \mathrm{C}$, counting was verified only in the plants submitted to the cold extraction process. The hot extraction process (infusion or tea) reduced the count of aerobic mesophiles and did not allow the detection of coliforms by the microbiological method, demonstrating that this is a safe way to use plant drugs.

Therefore, it is recommended that the quality control of vegetable drugs be more rigorous in addition to the adoption of good practices in the management of community gardens in order to comply with the relevant legislation and offer a safe product to the population.

\section{ACKNOWLEDGMENTS}

We would to thanks the Executive Board of Research and Post-Graduate Management - DEGPP UNIPAR, and the Coordination for the Improvement of Higher Level Personnel - Brazil (CAPES/CNPq) and the State College of Campo Benjamim Antonio Motter, district of Central Santa Cruz, Cafelandia-PR for the collaboration in the development of work.

\section{CONFLICT OF INTEREST}

The authors declare that there is no conflict of interest.

\section{AUTHORS' CONTRIBUTION}

All authors listed have made a substantial, direct and intellectual contribution to the work, and approved it for publication.

\section{FUNDING}

This work was supported by Executive Board of Research and Post-Graduate Management - DEGPP UNIPAR, and the Coordination for the Improvement of Higher Level Personnel - Brazil (CAPES/CNPq).

\section{ETHICS STATEMENT}

This article does not contain any studies with human participants or animals performed by any of the authors.

\section{DATA AVAILABILITY}

All datasets generated or analyzed during this study are included in the manuscript.

\section{REFERENCES}

1. Pessoa CC, de Souza M, Schuch I. Agricultura urbana e Seguranca Alimentar: estudo no municipio de Santa Maria - RS. Seg Alim Nutr. 2006;13(1):23-27. doi: 10.20396/san.v13i1.1842

2. de Carvalho PGB, Machado CMM, Moretti $\mathrm{CL}$, de 
Fonseca MEN. Hortalicas como alimentos funcionais. Hort Bras. 2006;24(4):397-404. doi: 10.1590/S010205362006000400001

3. Carvalho LM, Costa JAM, Carnelossi MAG. Qualidade em plantas medicinais. Aracaju: Embrapa Tabuleiros Costeiros, ISSN 1517-1329;162:2010.

4. Migliato KF, Moreira RRD, Mello JCP, et al. Controle de qualidade do fruto de Syzygium cumini (L.) Skells. Rev Bras Farmacogn. 2007;17(1):94-101. doi: 10.1590/ S0102-695X2007000100018

5. Ratajczak M, Kubicka MM, Kaminska D, Sawicka P, Dlugaszewska J. Microbiological quality of nonsterile pharmaceutical products. Saudi Pharm J. 2015;23(3):303-307. doi: 10.1016/j.jsps.2014.11.015

6. Henz GP, Alcantara FA. Hortas: O produtor pergunta, a embrapa responde. Brasilia - DF: Embrapa Informacoes Tecnologicas (Colecao 500 perguntas, 500 respostas). 2009.

7. Istan LPA, Mello JB, Oliveira TD, et al. Viabilidade de Hortas Comunitarias como Unidade Geradora de Renda. Revi. Int. Ens. Pesq. Ext. 2015;3(1):80-92.

8. de Melo JG, Martins JDGR, de Amorim ELC, de Albuquerque UP. Qualidade de Produtos a Base de Plantas Medicinais Comercializados no Brasil: Castanha-da-india (Aesculushippocastanum L.), Capim-limao (Cymbopogoncitratus (DC.) Stapf.) e Centela (Centellaasiatica (L.) Urban). Acta Bot Bras. 2007;21(1):27-36. doi: 10.1590/S010233062007000100004

9. Satomi LC, Soriani RR, Pinto TJA. Descontaminacao de Drogas Vegetais Empregando Irradiacao Gama e Oxido de Etileno: Aspectos Microbianos e Quimicos. Rev. Bras. Cienc. Farm. 2005;41(4):445-450. doi: 10.1590/ S1516-93322005000400006

10. Souza FS, Maciel CCS. Produtos Fitoterapicos e a Necessidade de Um Controle de Qualidade Microbiologico. Rev Elet Cie Per, . 2010;3(2):22-30.

11. Brandao MGL, Alves RMS, Moreira RA, et al. Qualidade de Amostras Comerciais de Chas de Plantas Medicinais. Rev. Bras. Pl. Med. 2002;5(1):56-59.

12. Araujo KRM, Kerntopf MR, Oliveira DR, et al. Plantas Medicinais No Tratamento De Doencas Respiratorias Na Infancia: Uma Visao Do Saber Popular. Rev. Rene. 2012;13(3):659-666.

13. Lirio VS, Dias CSC, Araujo ES, et al. Qualidade microscopica de chas: Comparacao com parametros legais. Rev. Hig. Al. 2001;15(82):27-32.

14. Ibge. Instituto Brasileiro de Geografia e Estatistica. Cafelandia Parana - PR, 2015. https://cidades.ibge. gov.br/brasil/pr/cafelandia/panorama. Acessado em 27 Abril de 2018.
15. Marcondes NSP, Esmerino LA. Qualidade microbiologica de plantas medicinais cultivadas em hortas domesticas. Publicatio UEPG - Cien Bio Saude. 2010;16(2):133-138. doi: 10.5212/Publ.Biologicas.v.16i2.0007

16. Silva N, Junqueira VCA, Silveira NFA, et al. Manual de Metodos de Analise Microbiologica de Alimentos. $3^{a}$ Ed. Sao Paulo: Varela. 2007:536.

17. Barbosa LN, Alves FCB, Andrade BFMT, et al. Effects of Ocimum basilicum Linn essential oil and sodium hexametaphosphate on the shelf life of fresh chicken sausage. J. Food Prot. 2014;77(6):981-986. doi: 10.4315/0362-028X.JFP-13-498

18. Bernadin KK, Witabouna KM, Julien CK, Mireille D. Microbial contamination of the stem of Mitragyna ciliata, a commercially available medicinal plant in the district of abidjan (Vote d' loivre). Res J Pharm Biol Chem Sci. 2018;5(4):404-415.

19. Ayres M, Ayres Junior M, Ayres DL, Santos AS. BioEstat: Aplicacoes Estatisticas nas Areas das Ciencias Biomedica. Belem: Universidade Federal do Para. 2007:364.

20. Brasil, Agencia Nacional de Vigilancia Sanitaria. Instrucao Normativa no. 4, de 18 de junho de 2014. Guia de Orientacao para Registro de Medicamento Fitoterapico e Registro e Notificacao de Produto Tradicional Fitoterapico. Brasilia, Ministerio da Saude. 2014.

21. Zaroni M, Pontarolo R, Abrahao WSM, et al. Qualidade microbiologica das plantas medicinais produzidas no estado do Parana. Rev Bras Farmacogn. 2004;14(1):2930. doi: 10.1590/S0102-695X2004000100005

22. Franco B, Landgraf M. Microbiologia dos alimentos. Rio de Janeiro: Atheneu. 2008:181.

23. Kneifel W, Czech E, Kopp B. Microbial contamination of medicinal plants: A review. Planta Med. 2002;68(17):515. doi: $10.1055 / \mathrm{s}-2002-20060$

24. Alterthum F, Carvalhal ML. Controle de microrganismos. In: Trabulsi LR et al. Microbiologia.3a ed. Atheneu, Sao Paulo. 1999:75-86.

25. Bugno A, Buzzo AA, Nakamura CT, et al. Avaliacao da contaminacao microbiana em drogas vegetais. Braz. J. Pharm. 2005;41(4):491-497. doi: 10.1590/S151693322005000400012

26. Souza-Moreira TM, Salgado HRN, Pietro RCLR. O Brasil no contexto de controle de qualidade de plantas medicinais. Rev Bras Farmacogn. 2010;20(3):435-440. doi: $10.1590 /$ S0102-695X2010000300023 